\section{RUTHERFORD: LIFE AND WORK TO THE YEAR 1919}

\author{
By Prof. H. R. ROBINSON, F.R.S.* \\ Queen Mary College (University of London)
}

I AM sure that we all ought to . . . give some of our recollections of those past and gone before they are lost for good."

These words, written by Rutherford himself in a letter to Rayleigh (March 1936), may well serve as my text. There are in existence excellent biographies of Rutherford, as well as obituary notices in many scientific and other journals; it will therefore be unnecessary for me to attempt to give a connected account of the first forty-eight years of Rutherford's life. I shall try to mention the more salient facts, though I shall necessarily be restricted to a bare minimum of detail, but I want above all to convey, so far as I can, some impression of the atmosphere of proud and contented endeavour and achievement which he maintained in his laboratories in Manchester. I do not under-estimate the difficulty of this ; Rutherford has filled so much of my mental horizon ever since I became his pupil in 1908, that I can scarcely expect to see everything concerning him in a perspective which others would necessarily recognize as true, but I will try to do it.

Fortunately, though Rutherford's genius was of a most uncommon kind, and his character and outlook difficult to assess, we have, in addition to personal recollections, one extremely valuable source of information ; mainly through Lady Rutherford's care and forethought, a great part of Rutherford's correspondence has been preserved and filed. We have, therefore, expressed in Rutherford's clear and vigorous English, much first-hand information that would otherwise have been lost to us.

Rutherford's paternal grandfather, George Rutherford, a wheelwright, left Scotland in 1842 to settle, with his family, in New Zealand. His son James, born in 1839, married in 1866 Martha Thompson, who had come to New Zealand at the age of twelve, and who for a short time before her marriage worked as a school teacher. Ernest Rutherford, born on August 30, 1871, was the fourth of the twelve children born of this marriage. He was born at Brightwater (Spring Grove), not far from Nelson ; four years later the family moved to Foxhill, and in 1882 to Havelock, both in the neighbourhood of Nelson. Ernest attended the State primary schools at Foxhill and Havelock, and apparently was very well taught at both schools. In 1886 he won a scholarship which took him to Nelson College, and at about the same time his family moved to Pungarehu, in North Island-not very far away-where his father, who had previously worked as a wheelwright, farmer, timber contractor and engineer, now concentrated on large-scale flax production.

Nelson College was evidently a model establish. ment, with an excellent headmaster in W. J. Ford and a fine mathematical master in Dr. W. S. Littlejohn, who gave Rutherford a sound start in mathematics and physics. Rutherford had a very successful three years in Nelson, winning awards not only in his best subject, mathematics, but also in Latin, French, English literature, history, physics and

* From the first Rutherford Memorial Lecture of the Physicel Soclety, delivered on November 6 . chemistry. It is on record that in June 1888 he was top of the sixth form in all subjects.

In 1889 he won a junior university scholarship which took him to Canterbury College, Christchurch, where he had again a continuous record of academic success. It was in Christchurch that he met, and became deeply attached to, Mary Newton, who became his wife in 1900.

Rutherford did his first research work-on the magnetization of iron in rapidly alternating fieldsin a draughty cellar of Bickerton's laboratory at Christehurch, and later he developed an ingenious magnetic detector of electromagnetic waves. This work, which would have been remarkable enough as the first performance of a young researcher under the most favourable conditions, must rank even higher when we think of the eircumstances in which it was done.

In 1895 the award of an 1851 Exhibition Science Scholarship enabled Rutherford to move to a great centre of research, and he elected to go to Cam. bridge-beating J. S. Townsend by a short head for the distinction of being the first research student to enrol under J. J. Thomson for the research degree newly instituted in Cambridge for workers from other universities. We find soon afterwards, in a letter to Mary Newton (October 3, 1895), "I am very glad I came to Cambridge. I admire Thomson quite as much as I thought I would, which is saying a good deal."

Here he continued work on Hertzian waves with his magnetic detector, and had notable successes in detecting waves at-for the time-great distances from their source. He soon, however (Easter 1896), dropped this to work with Thomson on the new subject of ions in gases, building up in a remarkably short time a very complete theory of gaseous conduction and determining experimentally many of the characteristic properties of the ions. From this work, by an entirely natural transition, he passed to the study of the recently discovered Becquerel rays, thereby finding his true life's work-radioactivity.

Here we may with advantage pause to recall the state of atomic physics at the time of Rutherford's first Cambridge period. It was one of almost unparalleled activity. In November 1895, Röntgen discovered X-rays, largely by accident. Becquerel's discovery of radioactivity in February 1896 was largely a second aceident arising out of Röntgen's discovery. It was, of course, the use of X-ray tubes as sources of ionization that made possible Rutherford's work on gaseous conduction.

About the same time Lorentz, the great pioneer of electron theory, was able to show that the newly discovered Zeeman spectral effect could be quantitatively explained by the assumption that spectral lines were the result of radiation by charged particles the specific charge of which was of the order of a thousand times that of the hydrogen ion in electrolysis. The electron, possessing this property, was isolated by J. J. Thomson in 1897, and shown to be a constituent of all ordinary matter-and this may be taken as the starting point of the modern electrical theory of the atom. The charge of the electron was measured soon afterwards by Townsend, Thomson and others; another essential link in the chain of discovery was Townsend's brilliant work on the diffusion of gaseous ions, which proved beyond doubt that the charge of a normal gaseous ion was identical in magnitude with that of a monovalent electrolytic ion. 
To some extent, therefore, Rutherford's entry into radioactivity and atomic physics was an accident of time and place- but this is the last occasion on which we can speak of any element of chance in his life's work. From this time on, he made and pursued his own line, and it would scarcely be an exaggeration to say that his subsequent achievement would have been little less imposing or significant if, in the whole period with which we are concerned, he had been completely oblivious to everything that went on outside his own mind and his own laboratory.

In 1898, when in full career, Rutherford made the difficult decision to leave Cambridge for the Macdonald research professorship of physics at McGill University, Montreal. Rutherford's estimate of himself at this time (which was clearly much less high than that which Thomson had formed) is quaintly expressed in a letter to Mary Newton. "It sounds rather comic to myself", he says, "to have to supervise the research of other men, but I hope I will get along all right." To anyone with the least knowledge of Rutherford's career, it must seem more than "rather comic" that Rutherford should have harboured such doubts. Even much later still, with an immensely fruitful period behind him, he showed himself inordinately gratified that foreigners like Hahn and Godlewski should think it worth while to go over to Canada to work with him.

The outstanding advance made in the McGill period was the development of the disintegration theory of radioactivity, first advanced by Rutherford and Soddy in 1903. By the time Rutherford left Montreal for Manchester, in 1907, this theory had been established beyond all reasonable doubt, and many of the details of the sequence of transformations had been elucidated. Rutherford had fully established, in his own mind at least, the nature of the alpha particles and had made rough measurements of their velocities and specific charge. $\mathrm{He}$ had also measured, with Barnes, a number of heating effects. His fame was now securely established, and he made of his laboratory what its founder had always hoped it would become, a permanent centre of research in Montreal. Higher education in Canada owes much to Rutherford-an indebtedness which has been generously and repeatedly acknowledged. On his side, Rutherford was at least equally ready to point out that the benefits of his association with Canada were by no means one-sided.

Rutherford's invitation to Manchester was largely due to the foresight of Arthur Schuster, who had marked him down some time before as the successor he would wish to see in the Langworthy chair of physics. Schuster was, for a physicist, a wealthy man-a fact on which Rutherford commented naively in a letter to his mother soon after his arrival in Manchester. He was, moreover, like so many of his race, not only generous, but also generous with rare discrimination, and when he retired to make way for Rutherford, he endowed, out of his own pocket, a readership in mathematical physicsthe one thing needed to complete the strength of the department. The Manchester laboratory was, for its time, well designed and equipped, and could produce adequate supplies of liquid air. It was less well fitted than MeGill for radioactive research, but Rutherford was never a stickler for luxury in working materials, and Feather has recorded in his biography that on June 6, 1907-less than three weeks after leaving Montreal-he was setting up an emanation electroscope in his new laboratory.
He was lucky in the men he found in the Manchester laboratory, most of whom turned over to work in radioactivity. He was perhaps most fortunate in finding Hans Geiger, a young graduate of Erlangen who had already done research under Schuster, and William Kay, a young mechanic who soon afterwards became head steward of the laboratories. To Kay, who surely ranks high among the world's greatest laboratory stewards, must go the credit for much of the smooth running of the laboratory.

Geiger was a well-trained and capable all-round physicist, with a considerable command of experimental technique, and his enthusiastic collaboration proved invaluable to Rutherford from the outset. Rutherford and Geiger's electrical counting of alpha particles-an amazing technical feat in those dayswas completed within a few months of Rutherford's arrival, and the paper was read before the Royal Society in June 1908, with that on the total charge carried by the particles.

An acute shortage of radioactive material in the laboratory, which faced Rutherford on his arrival, was soon relieved by a generous loan of $450 \mathrm{mgm}$. of radium bromide made to him by the Vienna Academy. Shortage of apparatus became rather serious as the work of the laboratory rapidly expanded, but no doubt Rutherford at this stage in his career had no difficulty in tapping a number of sources for research funds. Dr. Norman Smith, Registrar of the University of Manchester, has been kind enough to get for me the details of the annual grants made for apparatus and equipment to the Physics Department throughout Rutherford's tenure of the chair. For the pre-war years, these (excluding amounts earmarked for electrotechnics) averaged less than $£ 420$ a year, and in 1915-19 they dropped far below this figure. With these grants Rutherford worked wonders, and there can be few instances in the history of science of comparably rich yields from such modest investments.

Rutherford attracted to Manchester many experienced workers from other universities, and by now he had learnt to see nothing abnormal in this. $\mathrm{He}$ was so full of ideas for work that he needed every man he could get, and he trained as many as possible of his own students for research-it being quite usual for an undergraduate to begin on a selected problem in his third year at the University. Geiger, appointed research assistant, took over much of the training in radioactive measurements, and the training course was substantially that described in Makower and Geiger's "Practical Measurements in Radioactivity", published in 1912 .

Rutherford's most fruitful contribution to general atomic physics arose directly out of the results of an experimental problem which had been given to Ernest Marsden, one of the first of the Manchester trainees. This was the work on large-angle $\alpha$-particle scattering, carried out mainly by Geiger and Marsden in collaboration. As Rutherford put it many years later, "I told Geiger that young Marsden should begin a research. Why not let him see if any $\alpha$-particles can be scattered through a large angle? I did not believe that they would be. . . . It was quite the most incredible event that has ever happened to me in my life. It was almost as incredible as if you fired a 15-inch shell at a piece of tissue-paper and it came back and hit you" ("Background to Modern Science" (1938)). Thus originated Rutherford's nuclear theory of the atom, which he worked out in masterly fashion in 1911, and which changed the 
whole face of modern physics. The picture of the atom was completed by Bohr who, after working for some months in Rutherford's laboratory, first applied new quantum principles to the electrons of the nuclear atom, and by Moseley's brilliant work on the X-ray spectra of the elements, begun in Manchester in 1913.

It was characteristic of Rutherford that, though his research school was almost completely dispersed by the War of 1914-18, and though his time was so fully taken up by work of national importance at home and abroad, he should have contrived during those years to carry through successfully yet another epoch-making research. In experiments which he began in 1917 and ended early in 1919, generally with Kay alone to help in setting up apparatus and counting scintillations, he succeeded in showing that the nitrogen nucleus could be disrupted by the impact of a swift $\alpha$-particle, with the emission of a hydrogen nucleus. This, the first detected example of 'artificial transmutation', was the last work he published from Manchester ; its further development belongs to the second Cambridge period.

When I, as a young student, first met Rutherford in 1908, he was at the height of his powers-as he had indeed been for many years and as he remained right to the end of his life. I am sorry that I was not one of that generation of students of whom Rutherford wrote to Boltwood in October 1907, that "I find the students here regard a full professor as little short of Lord God Almighty". I can, however, testify that this was how Rutherford was regarded by the men of my year and those who followed us, though he was mistaken in believing--if he really did believe-that all full professors were objects of reverence to their students.

Officially, honours students had no lectures from the professor in their first year, but in practice we used regularly to attend his elementary lectures, partly because they were really illuminating, whatever their topic, and partly for the beautiful, and often sensational, experiments which Kay prepared for them. It seemed at times that it was Kay's taste in lecture demonstrations that really dictated the course of a lecture, and sometimes-not oftenKay was called upon to act as prompter, in response to appeals in which Rutherford presumably believed that he had reduced his normally huge voice to a scarcely audible whisper.

We also at times saw Rutherford walking along the corridors, singing lustily a tune recognizable as a rendering of "Onward, Christian Soldiers", and later we knew this to be a sign that research was going particularly well. I was interested to learn many years later, from an article by Prof. Norman Shaw, that this, I believe quite unconscious, habit dated from the McGill period. In less favourable times there was a melancholy dirge which no one ever identified-partly because, for obvious reasons, it was considered tactful to let him have the corridor to himself on these occasions, which were fortunately very rare.

We saw Rutherford in his most inspiring form at the physics colloquium, which met on Friday afternoons, the meetings being preceded by an enormous tea-party at which Lady Rutherford generally presided. Rutherford always addressed the first meeting of the session, giving with obvious enjoyment a summary of the main work done in the laboratory during the preceding session. The attendances were large, as many of the chemists and mathematicians came over to hear Rutherford, and in the atmosphere of sustained enthusiasm which he created, no young student could fail to feel that he was highly privileged to be of that community. I think we all felt then that we were living very near the centre of the scientific universe, and maturer reflection has only served to convince me more strongly that we were right. This sense of privilege naturally grew stronger in those who went on to do research, even in those of us who were doing relatively humble tasks and not, like Moseley, the things that were going to matter fundamentally for years to come.

I should like to state some of the more obvious reasons for Rutherford's extraordinary power as a leader of research. First, of course, there was his own unique and apparently almost intuitive grasp of the essentials of a problem. Next, his interest in the course of an investigation and his impatience to know the result were so passionate that they inevitably infected even the laziest of his co-workers. Then there washis incorrigible friendliness to even the least worthy of his research men; a man who is invited regularly to Sunday supper at his professor's house, who meets him nearly every day across the laboratory tea-table, who is generally treated as the social equal of an emeritus professor, and who is constantly and pointedly asked how his work is getting on, is likely to do more and better work than one who is left to feel that nobody wants him or his results very much. No doubt Rutherford's friendliness was partly due to his upbringing in New Zealand, and enhanced by nine years of life in Canada; no one who has seen much of New Zealanders in the mass can have failed to recog. nize that they are an unusually friendly and companionable people. Rutherford had these qualities in an extraordinarily high degree, and they undoubtedly helped to keep things going in the laboratory.

I would emphasize, too, in this connexion Rutherford's obvious and enormous delight in experimentation. I remember once, after he and I had wasted the whole of a fine Saturday afternoon in a quite ineffectual attempt to purify a very dirty little sample of radon with which we had hoped to work, Rutherford's saying with obvious sincerity, as he sucked contentedly at his pipe, "Robinson, you know, I am sorry for the poor fellows that haven't got labs. to work in !" It is not really surprising that in such an atmosphere a man like Andrade, arriving fresh from work on ionization in flames and from the making of metallic single crystals, should have found himself in next to no time working on gamma-rays, or that Darwin, the second of the Schuster Readers, coming under contract as a mathematician, should have suddenly found himself involved with gold-leaf electroscopes and an exporiment on a branching radioactive series.

This lecture began with a quotation from Rutherford. It may fittingly end with a quotation from von Helmholtz, part of an address given sixty years, almost to the day, before the death of Rutherford. Von Helmholtz was speaking of his own great teacher, Johannes Müller, and after referring to the student's neəd for "daily mental intercourse with teachers from whom he learns something of the workings of the thoughts of independent minds", he goes on to say, "Anyone who has once come in contact with one or more men of the first rank must have had his whole mental standard* altered for the rest of his life".

* von Helmholtz, "On Academic Freedom in German Universities" 1877 (Atkinson"s translation). The literal translation is "mental measuring-rod" 